\title{
Childhood leukaemia and poliomyelitis in relation to military encampments in England and Wales in the period of national military service, 1950-63
}

\author{
L J Kinlen, C Hudson
}

\begin{abstract}
Objective-To determine if any excess of childhood leukaemia was associated with the large and increasing numbers of national military servicemen in 1949 and 1950, particularly in rural districts. This would be a further test of the hypothesis that childhood leukaemia can originate in an infection, the transmission of which is facilitated by an increased number of unaccustomed contacts in the community.
\end{abstract}

Design-Rural and urban districts, aggregated by county, were ranked by proportion of servicemen, and five groups containing similar numbers of children were created. In addition, individual local authority districts were ranked and grouped in tenths. Mortality from childhood leukaemia $1950-3$ was examined in these groups. Data on infectious diseases were also examined, as well as data on leukaemia in later periods.

Setting-England and Wales.

Subjects-Children aged under 15 years.

Results - In 1950-3 but not subsequently a significant excess of leukaemia in children under 15 was found in the fifth of county groupings with the highest proportions of servicemen. This was due mainly to a significant excess in children under 2 years (and especially in those under 1 year) in rural districts. It was confirmed among the tenth of local authority districts with the highest proportion of servicemen. These rural areas showed significantly more notifications of, and deaths from, poliomyelitis among children than the rural average.

Conclusions - The findings support the infection hypothesis. That the excess of leukaemia was greatest in children under 1 year suggests transmission of infection among adults and thence to the fetus. The pattern of spread of poliomyelitis may also have been influenced by the presence of large numbers of servicemen.

\section{Introduction}

Recent findings indicate that population mixing, particularly in new towns in rural areas, can lead to increases in childhood leukaemia as predicted by a hypothesis on transmission of infection. ${ }^{12}$ A striking example of one type of population movement is that arising from national military service in Britain after the second world war. The introduction of military service in 1947, together with extensions of the service period in 1949 and 1950, produced striking demographic effects. In the 1951 census many areas had an appreciable excess of men, reflecting the presence of military camps. Indeed, in 15 local authority districts, mainly rural, servicemen outnumbered civilian men of working age.

The conditions of military life, particularly as they applied to men doing national service, prevented free contact with local people, so this is not a typical example of population mixing. Nevertheless, direct and indirect contacts between servicemen and local residents were inevitable and probably not confined to contact with those married "regulars" who lived in local communities. Moreover, the relatively crowded conditions in camps have particular relevance to the infection based hypothesis, as high levels of social contact promote transmission of infective agents.

Theory as well as previous findings would suggest that the effect of local concentrations of servicemen on the spread of infection would be greatest in rural districts. We therefore studied mortality from leukaemia among children in the early 1950s in these areas of England and Wales.

\section{Methods}

The period 1949-53 is the most appropriate period in which to study any early effects on mortality from leukaemia because national service was introduced in 1947. The 1951 census is the only source of details about the distribution of servicemen in England and Wales around that time, and this period is centred on the census year, as in the registrar general's extensive study of area mortality. ${ }^{3}$ However, no leukaemia data by area are available for 1949 , a year in which national service was extended from 12 to 18 months (as it was again in 1950 to two years ${ }^{4}$ ), causing substantial increases in servicemen. We therefore chose the period 1950-3 (as did the registrar general for cervical cancer, which also lacked area data for 1949). We used two methods.

Firstly, from published and unpublished tables dating from $1950^{5}$ we examined deaths from leukaemia in England and Wales in three available childhood age groups: below 1 year, 1-4 years, and 5-14 years. We then abstracted the most detailed data by areanamely, those for the aggregated rural and the aggregated urban districts of each county for the years 1950-3. The corresponding 1951 census populations, and proportions of servicemen, for these areas were obtained and those for the aggregated rural districts of counties were then arranged in ascending order of the proportions of servicemen ${ }^{6}$; the same procedure was followed for the urban areas. We created five groups from these accumulated populations; the groups consisted as closely as possible of one fifth of the total rural population of children aged under 15 in England and Wales; five similar urban groups were also formed. This arbitrary division into fifths represented a balance between obtaining reasonable expected numbers of deaths in each of the smaller (rural) groups and avoiding too low a limit for the proportions of servicemen in the category containing the highest concentration of servicemen. 
The age specific death rates from leukaemia in England and Wales at ages under 1, 1-4, 5-9, and 10-14 years in the period 1950-3 were applied to the relevant populations in each of the urban and rural fifths to produce expected numbers of deaths. The ratios of observed to expected deaths from leukaemia were expressed as ratios relative to the value for the group with the lowest proportion of servicemen (group I). Tests were applied for heterogeneity and for trend. The $95 \%$ confidence intervals were also calculated for the relative risks for the highest categories of servicemen where there was evidence of a significant upward trend in risk. ${ }^{8}$

Secondly, we realised that, instead of reflecting effects of proximity to large numbers of servicemen, a relation at the above county level might be indirect, owing to a relatively high incidence of the disease in groups of counties that happen to include large military encampments. We therefore investigated the matter at a finer level, that of individual local authority districts. No age specific data on leukaemia for such areas in 1950-3 are held by the Office of Population Censuses and Surveys, and computerised records of deaths date back only to 1959 . However, details of deaths from leukaemia in the 1950s had been provided by the registrar general for an earlier study, and with these it was possible to reproduce the published numbers of deaths from childhood leukaemia-for example, for $1950-3$ to within $17(98 \cdot 7 \%$ of the total). Details, including the local authority district of usual residence, were abstracted from these records and integrated in a computer file with population and other details from the 1951 census of the 1473 local authority districts of England and Wales. The 1473 districts were then arranged in ascending order of the proportion of servicemen among all men in $1951 .^{6}$ The previous division into fifths was inappropriate here as the unduly low limit for the highest fifth (category I, in which servicemen made up only $1.5 \%$ ) would have offset the advantage of the proportions in the highest local authority districts (up to 69\%). The earlier groupings were therefore halved, creating tenths; each category then had approximately a tenth of the children aged 0-14 years in England and Wales. In the individual local authority districts in the highest category the proportion of servicemen ranged from $5 \%$ to $69 \%$.

Ratios of observed to expected deaths were calculated for 1950-3 using national age specific rates, and the same approach was used for the two succeeding five year periods, 1954-8 and 1959-63. The same statistical tests were applied as with the county analyses.

We attempted to determine whether any excess of leukaemia affected the children of local residents, servicemen, or both. The only population data for children of servicemen in the 1950s are those of births in $1951 .^{4}$ As the standard regions each held similar proportions of servicemen who were married, ${ }^{6}$ births in 1951 were used as the basis for examining deaths from leukaemia at the youngest ages in servicemen's children, taken as being geographically distributed broadly in proportion to servicemen themselves.

Available data on deaths and notifications of childhood infectious diseases were examined by fifths of rural and urban districts and, for notifications of certain infections of special interest, by local authority districts, grouped in tenths.

\section{Results}

LEUKAEMIA IN COUNTY AGGREGATIONS OF URBAN AND OF RURAL DISTRICTS

Table I shows the proportions of servicemen in 1951 in the five urban and the five rural categories together with the corresponding numbers of children aged under 15. The uneven numbers of children in certain of the urban fifths reflect the large populations of certain counties intersected by "ideal" dividing points (Lancashire in group II, London and Middlesex in group IV). Urban-rural differences in the distribution of servicemen are reflected in their concentration in the highest urban $(1 \cdot 5-11 \cdot 3 \%)$ and rural $(9 \cdot 0-27 \cdot 1 \%)$ fifths (The appendix shows details of the composition, by county, of urban and rural fifths.)

Table II shows the observed to expected ratios of deaths from leukaemia, by urban and rural fifths, at

TABLE I-Percentages of servicemen in subgroups consisting as nearly as possible of similar numbers of children

\begin{tabular}{|c|c|c|c|c|c|c|c|}
\hline \multirow[b]{2}{*}{ Category } & \multicolumn{2}{|c|}{ Aggregates of urban counties } & \multicolumn{2}{|c|}{ Aggregates of rural counties } & \multirow[b]{2}{*}{ Category } & \multicolumn{2}{|c|}{ Aggregates of local authority districts } \\
\hline & $\%$ Of servicemen & $\begin{array}{c}\text { No of children } \\
\text { aged } 0-14 \text { years } \\
(000 \mathrm{~s})\end{array}$ & $\%$ Of servicemen & $\begin{array}{c}\text { No of children } \\
\text { aged } 0-14 \text { years } \\
(000 \mathrm{~s})\end{array}$ & & $\%$ Of servicemen & $\begin{array}{c}\text { No of children } \\
\text { aged } 0-14 \text { years } \\
(000 \mathrm{~s})\end{array}$ \\
\hline \multirow[t]{2}{*}{ I } & \multirow[t]{2}{*}{0.53} & \multirow[t]{2}{*}{1355} & \multirow[t]{2}{*}{$2 \cdot 05$} & \multirow[t]{2}{*}{369} & I & 0.31 & 971 \\
\hline & & & & & II & $0 \cdot 38$ & 975 \\
\hline \multirow[t]{2}{*}{ II } & \multirow[t]{2}{*}{0.69} & \multirow[t]{2}{*}{$2226^{\star}$} & \multirow[t]{2}{*}{$4 \cdot 17$} & \multirow[t]{2}{*}{374} & III & 0.45 & 961 \\
\hline & & & & & IV & $0 \cdot 50$ & 973 \\
\hline III & $1 \cdot 13$ & $936^{\star}$ & $5 \cdot 65$ & 396 & V & 0.59 & 929 \\
\hline \multirow[t]{2}{*}{ IV } & \multirow{2}{*}{$1 \cdot 46$} & \multirow{2}{*}{$1841^{\star}$} & \multirow{2}{*}{$9 \cdot 01$} & \multirow{2}{*}{378} & VII & 0.88 & 976 \\
\hline & & & & & VIII & 1.50 & 967 \\
\hline \multirow[t]{2}{*}{$\mathrm{V}$} & \multirow[t]{2}{*}{$11 \cdot 30$} & \multirow[t]{2}{*}{1442} & \multirow[t]{2}{*}{$27 \cdot 10$} & \multirow[t]{2}{*}{374} & IX & $5 \cdot 21$ & $972^{\star}$ \\
\hline & & & & & $\mathrm{X}$ & 68.65 & $967^{\star \star}$ \\
\hline
\end{tabular}

$\star 29 \%$ of children were in rural districts. $\star \star \star 63 \%$ of children were in rural districts.

TABLE II - Standardised ratio of observed to expected numbers of deaths from leukaemia by age group and proportion of servicemen in population of aggregated urban and rural parts of counties. Figures in parentheses are observed numbers of deaths

\begin{tabular}{|c|c|c|c|c|c|c|c|c|c|}
\hline \multirow[b]{2}{*}{ Category $^{\star}$} & \multicolumn{2}{|c|}{ Age $<1$ year } & \multicolumn{2}{|c|}{ Age $1-4$ years } & \multicolumn{2}{|c|}{ Age $5-14$ years } & \multicolumn{3}{|c|}{ Age $0-14$ years } \\
\hline & Urban & Rural & Urban & Rural & Urban & Rural & Urban & Rural & $\begin{array}{l}\text { Urban plus } \\
\text { rural }\end{array}$ \\
\hline 1 & $1 \cdot 00(6)$ & $\int(1)$ & $1.00(92)$ & $1.00(19)$ & $1.00(91)$ & $1.00(21)$ & $1.00(189)$ & $1.00(41)$ & $1 \cdot 00(230)$ \\
\hline II & $1.39(14)$ & $1.00\left\{\begin{array}{l}(4) \\
0\end{array}\right.$ & 0.94 (145) & $0.77(15)$ & $0.96(142)$ & $1 \cdot 13(24)$ & $0.97(301)$ & $0.99(43)$ & $0.97(344)$ \\
\hline III & $2.41(10)$ & $1.49 \quad(4)$ & $0 \cdot 71(46)$ & $1.23(25)$ & $0.71(44)$ & $0.88(20)$ & $0.76(100)$ & $1.07(49)$ & $0.84+(149)$ \\
\hline IV & $1.08(9)$ & $0.38 \quad(1)$ & 0.85 (112) & $1 \cdot 27(25)$ & $1 \cdot 11(134)$ & $1.31(28)$ & $0.98(255)$ & $1.24(54)$ & $1.02(309)$ \\
\hline V & $2 \cdot 40(15)$ & $4 \cdot 13$ (11) & $0.95(95)$ & $1.62(32)$ & $1 \cdot 20(116)$ & $1 \cdot 34(28)$ & $1 \cdot 12(226)$ & $1.65(71)$ & $1 \cdot 21^{\star}(297)$ \\
\hline \multirow{3}{*}{$\begin{array}{l}\mathrm{p} \text { Value for heterogeneity } \\
95 \% \text { Confidence interval, } \\
\text { group V v group I } \\
\text { Trend ( } \mathrm{p} \text { value) }\end{array}$} & $>0.05$ & $<0.01$ & $>0.05$ & $>0.05$ & $<0.05$ & $>0.05$ & $<0.05$ & $<0.05$ & $<0.01$ \\
\hline & & 1.25 to 15.21 & & 0.89 to 2.97 & 0.90 to 1.55 & & & $1 \cdot 11$ to $2 \cdot 4$ & 71.01 to 1.44 \\
\hline & $2.1(>0.05)$ & $6.0(<0.01)$ & $0.5(>0.05)$ & $5.0(<0.05)$ & $3.3<0.05$ & $1.4(>0.05)$ & $1.3(>0.05)$ & $8.7<<0.01$ & $5.6(<0.01)$ \\
\hline
\end{tabular}

*Category I has lowest proportion of servicemen; category $\mathrm{V}$ has highest proportion. 


\begin{tabular}{|c|c|c|c|c|c|c|c|c|}
\hline \multirow[b]{2}{*}{ Category ${ }^{\star}$} & \multicolumn{2}{|c|}{ Age $<2$ years } & \multicolumn{2}{|c|}{ Age 2-4 years } & \multicolumn{2}{|c|}{ Age $5-9$ years } & \multicolumn{2}{|c|}{ Age $10-14$ years } \\
\hline & $\begin{array}{c}\text { No of } \\
\text { observed } \\
\text { deaths }\end{array}$ & $\begin{array}{c}\text { Ratio of } \\
\text { observed to } \\
\text { expected } \\
\text { deaths }\end{array}$ & $\begin{array}{c}\text { No of } \\
\text { observed } \\
\text { deaths }\end{array}$ & $\begin{array}{l}\text { Ratio of } \\
\text { observed to } \\
\text { expected } \\
\text { deaths }\end{array}$ & $\begin{array}{c}\text { No of } \\
\text { observed } \\
\text { deaths }\end{array}$ & $\begin{array}{l}\text { Ratio of } \\
\text { observed to } \\
\text { expected } \\
\text { deaths }\end{array}$ & $\begin{array}{c}\text { No of } \\
\text { observed } \\
\text { deaths }\end{array}$ & $\begin{array}{l}\text { Ratio of } \\
\text { observed to } \\
\text { expected } \\
\text { deaths }\end{array}$ \\
\hline $\mathrm{I}+\mathrm{II}+$ & 32 & 1.00 & 103 & $1 \cdot 00$ & 75 & 1.00 & 48 & 1.00 \\
\hline III & 13 & $0 \cdot 82$ & 51 & 1.00 & 33 & 0.89 & 24 & 0.96 \\
\hline IV & 18 & $1 \cdot 10$ & 55 & 1.05 & 38 & 1.01 & 29 & $1 \cdot 19$ \\
\hline $\mathrm{V}$ & 9 & 0.58 & 44 & 0.88 & 33 & 0.92 & 21 & 0.90 \\
\hline VI & 12 & $0 \cdot 70$ & 59 & 1.08 & 51 & $1 \cdot 35$ & 22 & $0 \cdot 87$ \\
\hline VII & 21 & $1 \cdot 29$ & 49 & 0.94 & 42 & $1 \cdot 10$ & 26 & 1.05 \\
\hline VIII & 16 & 0.99 & 51 & 0.98 & 43 & $1 \cdot 14$ & 20 & 0.82 \\
\hline IX & 16 & 0.99 & 51 & 0.98 & 46 & $1 \cdot 22$ & 28 & $1 \cdot 13$ \\
\hline $\mathrm{X}$ & 31 & $1.90 \ddagger$ & 46 & 0.88 & 40 & 1.06 & 26 & 1.08 \\
\hline $\begin{array}{l}\text { p Value for heterogeneity } \\
\text { Trend }\end{array}$ & \multicolumn{2}{|c|}{$\begin{array}{l}<0 \cdot 05 \\
4 \cdot 7^{\star}\end{array}$} & \multicolumn{2}{|c|}{$\begin{array}{c}>0.05 \\
0.3\end{array}$} & \multicolumn{2}{|c|}{$\begin{array}{l}>0.05 \\
1.77\end{array}$} & \multicolumn{2}{|c|}{$\begin{array}{l}>0.05 \\
0.02\end{array}$} \\
\hline \multirow{2}{*}{\multicolumn{9}{|c|}{$\begin{array}{l}\text { Highest rural categories: } \\
\text { IX }\end{array}$}} \\
\hline & 6 & $1 \cdot 29$ & 14 & 0.93 & 11 & 1.00 & 10 & $1 \cdot 38$ \\
\hline & 21 & $2 \cdot 07 \S$ & 29 & $0 \cdot 88$ & 23 & 0.97 & 14 & 0.92 \\
\hline \multicolumn{9}{|l|}{ Highest urban categories: } \\
\hline IX & 10 & $0 \cdot 87$ & 37 & 1.00 & 35 & $1 \cdot 32$ & 18 & 1.03 \\
\hline $\mathrm{X}$ & 10 & 1.63 & 17 & $0 \cdot 87$ & 17 & $1 \cdot 21$ & 12 & $1 \cdot 34$ \\
\hline
\end{tabular}

${ }^{\star}$ Category I+ II has lowest proportion of servicemen; category $\mathrm{X}$ has highest proportion.

tIncludes $60 \%$ of missing cases (to nearest whole number), namely $2,4,2,2$ respectively in the four age groups.

$\$ 95 \%$ Confidence interval $1 \cdot 13$ to $3 \cdot 20$.

$\$ 95 \%$ Confidence interval $1 \cdot 39$ to $3 \cdot 37$

ages under 1 year, $1-4,5-14$, and $0-14$ years. The ratios are expressed relative to the value in the group with the lowest proportion of servicemen (group I) except for leukaemia in children aged below 1 year in rural areas, for which groups I and II were combined because there was only a single death in group I. A significant trend $(p<0.01)$ of leukaemia below age 15 together with a significant excess was found in the highest combined fifth for servicemen (ratio of observed to expected deaths, $1 \cdot 21$ ). This is mainly due to a more noticeable excess in rural areas, which show a ratio of 1.65 in the highest fifth and a significant trend $(p<0.01)$. This in turn reflects excess deaths in rural areas in children below 1 year (ratio $4 \cdot 13$; trend $p<0.01$ ) and aged $1-4$ years (ratio 1.62 ; trend $\mathrm{p}<0.05$ ).

\section{LEUKAEMIA IN INDIVIDUAL LOCAL AUTHORITY DISTRICTS}

In this more focused analysis with the individual local authority district as the basic unit (table III), there are major differences in the composition of the tenths from the groups in the previous analysis, even when the proportions of servicemen (shown in table I) are comparable. The highest tenth contains only $40 \%$ of the children in the highest rural fifth. (A county in the first fifth with a low proportion of servicemen in, say, its aggregated rural districts may contain certain local authority districts that have a high proportion and are in the top tenth-and vice versa, as shown in the appendix.)

With the above data the ratios of observed to expected deaths from leukaemia were expressed relative to the values in groups I and II. This was useful in allowing for the 17 missing death certificates of children aged below 15 in 1950-3. Since expected numbers were derived from national rates, some of the ratios will be underestimates. To prevent missing certificates biasing the standardised ratios we have made the extreme assumption (conservative to the hypothesis) that three (instead of one) fifths of these belonged to children in group I or II.

As for country aggregates of districts, the greatest excess was in children aged below 1 . The ratio of observed to expected deaths was $2 \cdot 14$ in the group with the highest proportion of servicemen (group X; trend, $\mathrm{p}<0.01)$, being greater in the rural $(2 \cdot 4)$ than the urban part (1.7). A non-significant excess was found in the rural part of group IX $(2 \cdot 38)$. In view of the trend in rural districts at ages $1-4$ in group $\mathrm{V}$ in table II, children aged 1 were examined with those below 1 , as in table III. This showed a significant excess in group $\mathrm{X}$ below age $2(1.9)$, together with a significant trend across the tenths $(\mathrm{p}<0.05)$. This excess was more definite in rural than urban parts of group $\mathrm{X}$. Indeed, relative to the rural parts of groups I and II, which had a low incidence ( 5 observed, 8.0 expected), the rural ${ }^{\omega}$ excess was appreciably greater than is shown in table $Z$ III. There was no excess at ages 2-4, 5-9, or 10-14.

An analysis by leukaemia subtype (not shown) was dominated by small numbers, myeloid lymphoid but not monocytic leukaemia were represented in the excess, which was somewhat greater for myeloid $\emptyset$ leukaemia (groups I and II, four deaths; group X, eight) and unspecified leukaemia (groups I and II, seven deaths; group $\mathrm{X}, 11$ ). Because the census slightly underestimated the numbers of infants below age 1 응 $(2 \cdot 1 \%),{ }^{10}$ we carried out an analysis using numbers of live births by local authority district in 1950-3 for $\mathbb{\perp}$ populations below age 1 , and in $1949-52$ for age 1 ; the findings were not greatly affected and the significance levels were unchanged.

In the period 1954-8 group X showed no significant excess of leukaemia in any of the four age groups shown in table III (unstandardised ratios of observed to expected deaths $0.76,0.93,0.89,0.86)$. Similarly, there was no excess in group $\mathrm{X}$ in 1959-63 whether the analysis was based on proportions of servicemen in 1951 or 1961 (data not shown). It may be noted in passing that in this period when all but $4 \%$ of local authority districts showed a decline in the numbers of $\frac{}{2}$ servicemen, there was one death from leukaemia in $N$ children below age 1 (expected 0.03 ) in the (rural) area $D$ with by far the greatest increase, an influx amounting to $31 \%$ of the 1961 male population of the district.

CHILDREN OF SERVICEMEN AND CIVILIANS COMPARED

There were seven deaths in children aged below 2 in servicemen's children in group X, of which five were in rural districts. It was judged impractical to obtain birth certificates for all affected children aged below 2, so this was done only for those in rural districts: all the above five cases from group $\mathrm{X}$ showed the father as a $\mathbb{\mathbb { D }}$ serviceman at the child's birth and death. In one $\mathbb{D}$ additional (rural) death (at age 1 ) in group X, the father 0 was shown as a serviceman only at the birth. All other leukaemias in children below age 2 in group $\mathrm{X}$ were 8 regarded as occurring in children of civilians; one of these had an obvious link to a military camp, the fatherô being described as a NAAFI canteen assistant at the child's death at age 2 months.

The above numbers were related to population 
for which outbreaks or epidemics occur only when the number (or the density) of infected and susceptible individuals in the population reaches some critical point, a point specific for the agent in question.

No excess of cases of leukaemia was recorded in 1954-8, a period little affected by the reductions in national service intakes, which started in $1957 . .^{4}$ By 1961, however, shortly before national service finally ended in 1963, there were 232097 ferver servicemen in the country than in 1951. The failure of the increase of leukaemia to persist beyond the period $1950-3$ is consistent with the number of susceptible individuals declining to below some critical level, as would happen at the end of an epidemic of any infective disorder. ${ }^{13}$

It is noteworthy that the significant increase of leukaemia in young children is restricted to those under 2 years. Leukaemia at this age is less common than at ages 2-4, when characteristically there is a peak in incidence. Differences also exist in prognosis and cell type: below age 2 leukaemia is more commonly myeloid; when it is lymphatic, it is more often null or T cell in type than at ages $2-4 .{ }^{14}$ Moreover, in the period 1930-60, when mortality from leukaemia at ages 2-4 increased steadily, the rates below age 2 remained fairly constant. In the period covered by this study, the disease was uniformly fatal.

The excess of leukaemia was mainly in rural districts, five features of which may be relevant. Firstly, by analogy with certain infectious diseases, a greater proportion of the population of rural districts would be susceptible to the agent(s) postulated as underlying childhood leukaemia because of the low population density of these districts and their separation from population centres. Secondly, camps in rural districts held more national servicemen than urban camps, as was reflected in their higher proportions of servicemen aged 18 and 19, , among whom there would presumably have been more crowding than among "regulars." Thirdly, unlike garrison towns, which were scattered, rural districts in the group with the highest proportion of servicemen (group X) often bordered each other - as in Berkshire, Wiltshire, Norfolk, and Hampshireand this might intensify their effects. Fourthly, a large rural camp probably makes a greater overall impact on the population in its vicinity than would an urban camp. Finally, most RAF stations are in rural districts. It is conceivable that the relatively high social class of the RAF national service intake 4 might include more people susceptible to infection, which might increase the severity of the postulated epidemics in those rural districts.

Military camps, with large numbers of young men in relatively crowded conditions and frequent arrivals of new susceptible and infected individuals, are well $\frac{\bar{m}}{\vec{D}}$ known as settings for epidemics of infectious diseases. $\stackrel{\mathbb{D}}{\mathcal{D}}$ Such conditions favour transmission not only of infec- D tive agents but also of larger doses of them through repeated contacts with infected individuals. These conditions may therefore be particularly relevant to the hypothesis that childhood leukaemia is a rare response to a commoner infection as intensity of exposure $\frac{0}{3}$ may determine which infected children develop leukaemia. ${ }^{12}$ Meningococcal infections ${ }^{15}$ and haemolytic streptococcal infections ${ }^{16}$ have been studied in military camps. Outbreaks of meningococcal infection in such situations are well known, though these mainly occurred in wartime, when the density and mixing of troops was unusually high; then civilians and their children were also often affected.

Certain epidemics of poliomyelitis affected rural $\omega$ areas more severely than urban areas; this implies that there was a higher proportion of susceptible individuals in rural areas. In this study the rural areas with the greatest proportion of servicemen had significantly more poliomyelitis among children than the rural average both in terms of notifications and deaths (tables IV and V). This is an infection, like that postulated as underlying childhood leukaemia, in which only a small proportion of those infected develop an illness.

\begin{tabular}{|c|c|c|c|c|c|c|c|c|c|c|c|c|c|c|c|c|c|c|c|c|c|c|c|c|c|}
\hline & \multicolumn{10}{|c|}{ Grouping of county aggregates } & \multirow{2}{*}{\multicolumn{2}{|c|}{$\begin{array}{l}\text { No of districts in } \\
\text { highest 10th of } \\
\text { local authority } \\
\text { districts }\end{array}$}} & & \multicolumn{10}{|c|}{ Grouping of county aggregates } & \multirow{2}{*}{\multicolumn{2}{|c|}{$\begin{array}{l}\text { No of districts in } \\
\text { highest 10th of } \\
\text { - local authority } \\
\text { districts }\end{array}$}} \\
\hline & \multicolumn{5}{|c|}{ Urban } & \multicolumn{5}{|c|}{ Rural } & & & & \multicolumn{5}{|c|}{ Urban } & \multicolumn{5}{|c|}{ Rural } & & \\
\hline & I & II & III & IV & $\mathrm{V}$ & I & II & III & IV & V & Urban & Rural & & I & II & III & IV & $\mathrm{V}$ & I & II & III & IV & $\mathrm{V}$ & Urban & Rural \\
\hline Anglesey & & & III & & & & & & IV & & 0 & 1 & London & & & & IV & & & & & & & 2 & \\
\hline Bedfordshire & & & III & & & & & & & $\mathrm{V}$ & 2 & 2 & Merionethshire & & & & & V & & & & & V & 1 & 2 \\
\hline Berkshire & & & & & V & & & & IV & & 1 & 6 & Middlesex & & & & IV & & & & & & & 1 & \\
\hline Brecknockshire & & & & & V & & II & & & & 1 & 1 & Monmouthshire & & II & & & & I & & & & & 0 & 0 \\
\hline Buckinghamshire & & & & & V & & & & IV & & 2 & 2 & Montgomeryshire & I & & & & & I & & & & & 0 & 0 \\
\hline Caernarvonshire & I & & & & & I & & & & & 0 & 0 & Norfolk & & & III & & & & & & & $\mathrm{V}$ & 0 & 9 \\
\hline Cambridgeshire & & II & & & & & & & IV & & 0 & 2 & Northamptonshire & I & & & & & I & & & & & 0 & 0 \\
\hline Cardiganshire & I & & & & & I & & & & & 0 & 0 & Northumberland & & & III & & & & II & & & & 0 & 2 \\
\hline Carmarthenshire & I & & & & & I & & & & & 0 & 0 & Nottinghamshire & & & III & & & & & III & & & 0 & 3 \\
\hline Cheshire & & & & & $\mathrm{V}$ & & & III & & & 2 & 2 & Oxfordshire & & & III & & & & & & & $\mathrm{V}$ & 0 & 3 \\
\hline Cornwall & & & & & V & & & & IV & & 4 & 4 & Pembrokeshire & & & & & $\mathrm{V}$ & & II & & & & 1 & 1 \\
\hline Cumberland & & & & IV & & & II & & & & 0 & 2 & Peterborough & & II & & & & & & & & V & 0 & 1 \\
\hline Denbighshire & & & & & $\mathrm{V}$ & I & & & & & 0 & 0 & Radnorshire & & & & IV & & I & & & & & 0 & 0 \\
\hline Derbyshire & & II & & & & I & & & & & 0 & 0 & Rutland & & & & IV & & & & & & $\mathrm{V}$ & 0 & 1 \\
\hline Devon & & & & & V & & & III & & & 2 & 4 & Shropshire & & & & & $\mathrm{V}$ & & & & & V & 1 & 7 \\
\hline Dorset & & & & & V & & & & & V & 2 & 3 & Somerset & & & & IV & & & & III & & & $i$ & 4 \\
\hline Durham & I & & & & & I & & & & & 0 & 2 & Staffordshire & I & & & & & & & & IV & & 0 & 3 \\
\hline Essex & & & & IV & & & II & & & & 2 & 3 & Suffolk: & & & & & & & & & & & & \\
\hline Flintshire & & II & & & & & & & IV & & 0 & 2 & East Suffolk & & & & IV & & & & & IV & & 1 & 3 \\
\hline Glamorganshire & I & & & & & & & III & & & 0 & 1 & West Suffolk & & & & & $\mathrm{V}$ & & & & & $\mathrm{V}$ & 1 & 3 \\
\hline Gloucestershire & & & III & & & & & III & & & 0 & 5 & Surrey & & & & & $\mathrm{V}$ & & II & & & & 3 & 1 \\
\hline Hampshire & & & & & $\mathrm{V}$ & & & & & $\mathrm{V}$ & 7 & 9 & Sussex: & & & & & & & & & & & & \\
\hline Herefordshire & & & & & V & & & & IV & & 0 & 1 & East Sussex & & & III & & & & II & & & & 0 & 1 \\
\hline Hertfordshire & & & III & & & I & & & & & 1 & 1 & West Sussex & & & III & & & & & III & & & 0 & 1 \\
\hline Huntingdonshire & & & III & & & & & & & V & 0 & 2 & Warwickshire & I & & & & & & & III & & & 0 & 4 \\
\hline Isle of Ely & & & & & V & I & & & & & 1 & 0 & Westmoreland & I & & & & & I & & & & & 0 & 0 \\
\hline Isle of Wight & & & & & V & & II & & & & 1 & 0 & Wiltshire & & & & & $\mathrm{V}$ & & & & & $\mathrm{V}$ & 2 & 9 \\
\hline Kent & & & & & V & & II & & & & 10 & 4 & Worcestershire & & II & & & & & & III & & & 0 & 3 \\
\hline Lancashire & & II & & & & & & & IV & & 3 & 2 & Yorkshire: & & & & & & & & & & & & \\
\hline Leicestershire & & & III & & & I & & & & & 0 & 0 & East Riding & & II & & & & & & & IV & & 0 & 2 \\
\hline Lincolnshire: & & & & & & & & & & & & & North Riding & & & & IV & & & & & & $\mathrm{V}$ & 2 & 7 \\
\hline Holland & & II & & & & I & & & & & 0 & 0 & West Riding & & II & & & & & II & & & & 0 & 5 \\
\hline Kesteven & & & III & & & & & & & $\mathrm{V}$ & 0 & 3 & & & & & & & & & & & & & \\
\hline Lindsey & & & & IV & & & & & IV & & 0 & 5 & & & & & & & & & & & & & \\
\hline
\end{tabular}


It is difficult to offer an alternative to an infective explanation for the present findings. A possible relation between leukaemia in children under 1 year and maternal use of drugs such as marijuana ${ }^{17}$ cannot be relevant here, since the period in question (1950-3) long preceded any appreciable use of such drugs in Britain. Similarly, a hypothesis about mutations caused by delayed exposure to immunological challenges ${ }^{18}$ cannot be invoked since it would apply only in leukaemia occurring later than the ages that show the excess in this study.

The findings support the hypothesis that prompted this study - that the presence of large numbers of servicemen, particularly in rural districts, was conducive to an increase in the incidence of childhood leukaemia. They also point to an infection transmitted among adults, as also implied by a recent study of the effects of the population mixing associated with increases in commuting. ${ }^{19}$ The increase was greatest in children under 1 year, which suggests intrauterine infection with transmission from the serviceman population, presumably-directly or indirectly-by the husband.

We thank David Dipple, Gina Birch, and Janette Wallis for computing help, Helena Strange for clerical work, and Susan Hill for secretarial assistance. We are also grateful to Dr P Cook-Mozaffari, Dr R Mole, Professor P G Smith, Air Marshal Sir Thomas Stonor, and Professor N Wald for helpful comments. We thank the historical branches of the army and of the Royal Air Force and Mr Trevor Royle for information about national service.

The CRC Cancer Epidemiology Research Group is entirely funded by the Cancer Research Campaign, from which LJK holds a Gibb fellowship.
1 Kinlen LJ. Evidence for an infective cause of childhood leukaemia: com arison of a Scottish new town with nuclear reprocessing sites in Britain. ancet 1988;ii:1323-7.

2 Kinlen LJ, Clarke K, Hudson C. Evidence from population mixing in British new towns 1946-85 of an infective basis of childhood leukaemia. Lance 1990 ;ii:577-82.

3 Registrar General. Decennial supplement England E Wales 1951. Area mortality. London: HMSO, 1958.

4 Royle T. The best years of their lives. The national service experience 1945-63. London: Michael Joseph, 1986.

5 Registrar General. Statistical review of England and Wales 1950 and 1951. Tables. Part I medical. London: HMSO, 1952, 1953: table 20.

6 General Register Office. Census 1951 England and Wales: occupation tables. London: HMSO, 1956.

7 Breslow NE, Day NE. Statistical methods in cancer research. Vol II. The design and analysis of cohort studies. Lyons: International Agency for Research on Cancer, 1987:71,96. (IARC Scientific Publications no 82.)

8 Breslow NE, Day NE. Statistical methods in cancer research. Vol II. The design and analysis of cohort studies. Lyons: International Agency for Research o Cancer, 1987:93-5. (IARC Scientific Publications no 82.)

9 Registrar General. Decennial supplement England and Wales 1951. Occupationa mortality part II. Volume 2: tables. London: HMSO, 1957:table 1.

10 Werner B. Infants aged under one in the census 1861-1981. Population Trend 1984;38:18-24.

11 Titmuss RM. Problems of social policy. In: Hancock WK, ed. History of the second world war. London: HMSO, 1950:245.

12 Campbell D. The unsinkable aircraft carrier. London: Michael Joseph, 1984.

3 Anderson RM, May RM. Directly transmitted infectious diseases: control by vaccination. Science 1982;215:1053-60.

14 Greaves MF. Subtypes of acute lymphoblastic leukemia: implications for pathogenesis and epidemiology. In: Magrath IT, O'Conor GT, Ramot B eds. Pathogenesis of leukemias and lymphomas: environmental influences. New York: Raven 1984 : 129-39.

15 Glover JA. Observations on the meningococcus carrier rate and their application to the prevention of cerebrospinal fever. In: Gordon MH application to the prevention of cerebrospinal fever. In:
Cerebro-spinal fever. Studies among the military forces, 1915-19.

16 Coburn AF, Young DC. The epidemiology of hemolytic streptococcus during world war II in the United States Navy. Baltimore: Williams and Wilkins, 1949.

17 Robison LL, Buckley JD, Daigle AE, Wells R, Benjamin D, Arthur DC, et al. Maternal drug use and risk of childhood non-lymphoblastic leukemi among offspring. Cancer 1989;63:1904-11.

18 Greaves MF. Speculation on the cause of childhood acute lymphoblastic leukemia. Leukemia 1988;2:120-5.

19 Kinlen LJ, Hudson CM, Stiller CA. Contacts between adults as evidence for an infective origin of childhood leukaemia: an explanation for excess near nuclear establishments in West Berkshire? Br f Cancer 1991;64:549-54.

(Accepted 16 August 1991)

\title{
A randomised trial comparing endometrial resection and abdominal hysterectomy for the treatment of menorrhagia
}

\author{
Michael J Gannon, Edmund M Holt, John Fairbank, Michel Fitzgerald, M Alison Milne, \\ Alan M Crystal, John O Greenhalf
}

Department of Obstetrics and Gynaecology, Royal Berkshire Hospital,

Reading RG1 5AN

Michael J Gannon, MRCOG registrar

Edmund M Holt, FRCOG, consultant

John Fairbank, MRCOG, senior registrar

M Alison Milne, MB, clinical assistant

Alan M Crystal, MRCOG, consultant

John O Greenhalf, FRCOG, consultant

Regional Technical College, Galway, Republic of Ireland

Michel Fitzgerald, MSC, statistician

Correspondence to: Dr M J Gannon, University Department of Obstetrics and Gynaecology, Box No CW 34, General Infirmary, Leeds LS2 9NS.

\section{Abstract}

Objective-To determine the advantages and disadvantages of endometrial resection and abdominal hysterectomy for the surgical treatment of women with menorrhagia.

Design-Randomised study of two treatment groups with a minimum follow up of nine months.

Setting-Royal Berkshire Hospital, Reading.

Subjects -51 of 78 menorrhagic women without pelvic pathology who were on the waiting list for abdominal hysterectomy.

Treatment-Endometrial resection or abdominal hysterectomy (according to randomisation). Endometrial resections were performed by an experienced hysteroscopic surgeon; hysterectomies were performed by two other gynaecological surgeons.

Main outcome measures-Length of operating time, hospitalisation, recovery; cost of surgery; short term results of endometrial resection.

Results-Operating time was shorter for endometrial resection (median 30 (range 20-47) minutes) than for hysterectomy (50 (39-74) minutes). The hospital stay for endometrial resection (median 1 (range 1-3) days) was less than for hysterectomy (7 (5-12) days). Recovery after endometrial resection (median 16 (range 5-62) days) was shorter than after hysterectomy (58 (11-125) days). The cost was $£ 407$ for endometrial resection and $£ 1270$ for abdominal hysterectomy. Four women (16\%) who did not have an acceptable improvement in symptoms after endometrial resection had repeat resections. No woman has required hysterectomy during a mean follow up of one year.

Conclusion-For women with menorrhagia who have no pelvic pathology endometrial resection is a useful alternative to abdominal hysterectomy, with many short term benefits. Larger numbers and a longer follow up are needed to estimate the incidence of complications and the long term efficacy of endometrial resection.

\section{Introduction}

Endometrial resection is gaining widespread acceptance as a surgical treatment for menorrhagia. A survey in August 1990 showed that 36 British centres had performed a total of over 4000 endometrial ablation procedures.' Seventy per cent of these were endometrial resections with the urological resectoscope.

The technique was initially used for treating intractable uterine bleeding in women who were unfit for hysterectomy because of blood dyscrasias or extreme anaesthetic risk. ${ }^{2}$ Follow up showed that most remained amenorrhoeic. Transcervical endometrial resection was subsequently performed for healthy women who suffered from menorrhagia. ${ }^{3}$ Most of those who had a complete resection of the endometrium became amenorrhoeic. 